\title{
Evidence of olive mild mosaic virus transmission by Olpidium brassicae
}

\author{
Carla M. R. Varanda • Marta S. M. R. Silva • \\ Maria do Rosário F. Félix • Maria Ivone E. Clara
}

\begin{abstract}
Transmission of three strains of OMMV by an Olpidium sp. was evaluated and compared. The three strains were 1) an OMMV wild type (WT) recovered from olive trees, 2) an OMMV variant (L11) obtained after 15 serial passages of single local lesions induced in Chenopodium murale plants, and 3) a construct OMMV/OMMVL11 in which the coat protein $(\mathrm{CP})$ gene replaced that of the wild type. A single-sporangial culture derived from Chinese cabbage (Brassica pekinensis) used as a bait plant grown in soil of an olive orchard, was identified as Olpidium brassicae based on the size and sequence of the

zoospores, estimated spectrophotometrically, was 7\% in the case of OMMV, and practically nil in the case of the other two viral strains. Substitution of the coat protein (CP) gene of OMMV by that of the OMMV L11 strain, drastically reduced viral transmissibility in the presence of zoospores to the level of that observed in their absence. Our data shows that OMMV soil transmission is greatly enhanced by $O$. brassicae zoospores and that the viral $\mathrm{CP}$ plays a significant role in this process, most likely by facilitating virus binding and later entrance into the host plant roots.
\end{abstract} generated amplicon in PCR specific tests. Each of the three virus strains was soil transmitted to cabbage roots in the absence of the fungus at similar rates of 30 to $40 \%$. Separate plant inoculation by $O$. brassicae zoospores incubated with each viral strain resulted in enhanced transmission of OMMV, reaching $86 \%$ of infection whereas that of the other two strains remained practically unaffected at $c a$. 34\%. Binding assays showed that the amount of virus bound to

C. M. R. Varanda • M. S. M. R. Silva • M. d. F. Félix •

M. I. E. Clara

Instituto de Ciências Agrárias e Ambientais Mediterrânicas,

Universidade de Évora,

7002-554 Évora, Portugal

C. M. R. Varanda $(\varangle) \cdot$ M. S. M. R. Silva • M. d. F. Félix

M. I. E. Clara

Departamento de Fitotecnia, Universidade de Évora,

7002-554 Évora, Portugal

e-mail: carlavaranda@uevora.pt

Keywords Coat protein · Fungal transmission . OMMV mutants

\section{Introduction}

Olive mild mosaic virus (OMMV) is a recent member of genus Necrovirus, family Tombusviridae originally isolated from olive trees in Portugal (Cardoso et al. 2005). New sequence data submitted to Genbank (accession numbers EF 201608, EF 201607, EF 201606 and EF 201605) reveals that it also infects tulips, and is the causal agent of Augusta disease (Pham et al. unpublished), which was previously ascribed to Tobacco necrosis virus (TNV) (Kassanis 1949). The virus has a diameter of $c a .28 \mathrm{~nm}$ and a single stranded positive-sense RNA genome, $3683 \mathrm{nts}$ long, containing 5 open reading frames (ORF). 